\title{
THE IMPORTANCE OF EXCELLENCE MODELS IN ASSESSING THE INNOVATIVE ACTIVITY OF ENTERPRISES
}

\author{
Joanna MACHNIK-SŁOMKA \\ Politechnika Śląska, Wydział Organizacji i Zarządzania, Katedra Zarządzania i Logistyki; \\ joanna.machnik-slomka@polsl.pl, ORCID: 0000-0001-5387-5909
}

Purpose: The purpose of the article is to identify the importance of excellence models with respect to the evaluation of innovative activity and to present selected excellence models in this area.

Design/methodology/approach: A critical analysis of domestic and foreign literature on the subject of excellence models in the field of innovation activity.

Findings: This article presents the theoretical background for the possibility of assessing innovation activities, innovation management practices by means of excellence models. The analysis is conducted within the perspective of the broad concept of excellence. The choice of the approach to excellence in innovation management determines the scope of possibilities and the way in which it can be assessed. The results of the analysis show that excellence models in the area of innovation management can play a crucial role in reviewing and diagnosing organisations in this field, monitoring needs and performance and identifying areas for improvement and defining directions for further improvement.

Originality/value This paper presents methods of assessing innovative activity using excellence models as well as analysis of identified selected excellence models in the area of innovation management.

Keywords: excellence models, excellence, innovation management, evaluation methods.

Category of the paper: literature review.

\section{Introduction}

The multifaceted nature of issues related to innovation management requires the search for methods and tools to ensure its measurement and assessment. One of the ways of assessing innovative activity and applied management practices in this area may be excellence models. The matter of excellence, including business excellence, is a subject frequently addressed by many authors (Tatarkiewicz, 1976; Peters, Waterman,1982; Szczepańska, 2011; Lichtarski, 2014; Stańczyk-Hugiet, 2014; Juchniewicz, 2016; Kacała, 2013; Kłosowska-Lasek, 2019). 
The notion of business excellence, introduced by T. Peters and R.H. Waterman, referring to an organisation, has become the basis for many concepts, which include, for instance, excellence models (Szczepańska, 2012). J.M. Lichtarski emphasises that organisational excellence models are becoming increasingly popular (Lichtarski, 2014). Many authors believe that the application of these models may prove to be an efficient tool for reviewing and diagnosing organisations, monitoring needs and results as well as identifying areas for improvement (Bovaird, Loeffler, 2009; Grigoroudis, Siskos, 2010; Haffer, 2011; Martusewicz, Szumowski, 2018). In the field of innovation management, there is also a growing interest in the development and implementation of excellence models at international level. Research in this area was conducted, among others, by Žižlavský (2011). The author, when evaluating models for measuring excellence in innovation management and the impact on success, indicated the directions of further development of these models. Žižlavský emphasised the need to further research especially in the area of specific dimensions of innovation management, eliminating gaps, integrating different types of innovation, combining performance-related indicators and root cause indicators (Žižlavský, 2011). The analysis of existing literature on the subject indicates a certain lack of research into the development of diagnostic design standards by means of excellence models in the field of innovative activities. Given the growing significance and interest in the subject of innovation management, which should be one of the key competences of modern enterprises, excellence models in this area are becoming increasingly relevant.

The purpose of the article is to identify the importance of excellence models with respect to the evaluation of innovative activity and to present selected excellence models in this area. The analysis of the importance of excellence models has been presented in the perspective of the broadly understood concept of excellence in management and quality sciences with particular reference to innovation management. These considerations are part of the conceptual work related to the development of a model in the area of innovation management.

\section{Excellence in management and quality sciences in terms of innovation management}

The concept of excellence is analysed in the literature on the subject from the perspective of various areas and fields of scientific research, including humanities, social sciences, including management and quality sciences, praxeology. The concept of excellence has been an issue present in the theory and practice of management and quality for several decades and constitutes an important research area (Juchniewicz, 2016). The work of Tatarkiewicz W. should be mentioned here (1976); or the book In Search of Excellence by Peter T.J., Waterman 
R.H. (1982). The organisations' pursuit of excellence is one of the ways of improving the operations and strengthening their potential (Kacała, 2013).

Excellence, regardless of its common use, is an ambiguous concept and is interpreted in a variety of ways in the literature. Tatarkiewicz distinguishes, among others, the following definitions of the concept of excellence (Tatarkiewicz, 1976): excellent is that what fulfils all its proper functions (Galen, Aristotle); that what has achieved its goal (Aristotle); that what contains all its due parts and what is so good that it cannot be better in its kind (Aristotle); that what is harmonious and built according to a single principle; and what is excellent is harmony in diversity (Wolff, Baumgarten).

With reference to the organisation, the concept of excellence indicates new directions in the way of perceiving it and in the relations between its elements (Szczepańska, 2011). According to the author, excellence can be referred to (Szczepańska, 2011):

- organisation (excellent organisation),

- activities of the organisation (activities, excellent processes),

- products of the organisation's activity (excellent products),

- elements of the organisation (excellent elements, e.g. organisation structure),

- relationships between the organisation and its environment (excellent relationships with stakeholders).

Zbierowski defines organisational excellence as "an organisation that achieves consistently higher-than-average results through the efficiency-oriented efforts of its participants operating in a specific infrastructure environment of organisational excellence" (Zbierowski, 2012).

The process of evolution of excellence concept, which is compatible with A.A. Waal's stages of evolution, has been described by E. Stańczyk-Hugiet who distinguishes the following five stages (Stańczyk-Hugiet, 2014):

- Excellence 1.0 (soft factors) - this is the first stage in the evolution of the concept of excellence, which was described by seeking answers to the question about the sources of success of Japanese companies.

- Excellence 2.0 (change) — is a stage of evolution for which two competences are crucial in the pursuit of excellence in changing environmental conditions: quality and flexibility. Hence, the focus of this stage of evolution is on continuous improvement and change.

- Excellence 3.0 (learning) — this stage is primarily linked to the growing importance of learning and knowledge processes. The concept of excellence is associated with quality and learning (these are the two building blocks of excellence).

- Excellence 4.0 (excellence models) - is a stage that involves developing analytical criteria (confirmed by a certificate), the fulfilment of which confirms the organisation's drive for excellence. Excellence models serve as a benchmark for comparison and selfassessment. The main weaknesses of the models at this stage include the fact that they 
do not take into account the strategic context, which should include organisational conditions in a comprehensive and differentiated way.

- Excellence 5.0 (integrated improvement concept) — is a stage that involves permanent change, in which strategic management is the key concept, taking into account many dimensions - internal and external, analysis and implementation, hard and soft elements. This stage addresses the defined weaknesses of the previous stage of excellence evolution.

The presented process of evolution of the concept of excellence according to the author demonstrates the convergence of the processes of distinguishing forms of excellence with the selection processes, which may be a sign of changes according to the evolution of the external environment (Stańczyk-Hugiet, 2014). This helps to diagnose how far the organisation differs from the "ideal" and what measures should be taken to approach the "excellent" state. (Stańczyk-Hugiet, 2014).

The issue of excellence in innovation management in the literature is considered to be a complex and multidimensional question. K.N. Dervitsiotis while discussing the framework for assessing an organisation's innovation excellence, treats innovation as an ability to generate value in the future (Dervitsiotis, 2010). The author describes the framework for assessing an organisation's innovation excellence, which includes: ability to generate value in innovation management and timely identification of ways to measure and improve it (Dervitsiotis, 2010). Spitzley A., Rogowski T., Garibaldo claim that excellence in innovation management can be defined as the fact that innovation is a non-linear, multidimensional, dynamic phenomenon and depends greatly on the ability to use resources and the potential to co-create different dimensions (Spitzley, Rogowski, Garibaldo, 2007). According to the authors, the key factor is an integrated and coherent set of policies and practices (Spitzley, Rogowski, Garibaldo, 2007). J. Brocke and M. Rosemann, however, emphasise the importance of the concept of process excellence management as a key factor in achieving better results and innovation through business process management (Brocke, Rosemann, 2010/2015). Mielcarek highlights that the process approach itself recognises the aspects which are the main success factors in innovation management (Mielcarek, 2017).

\section{Excellence models as instruments for assessing innovative activity}

In the literature on the subject we can distinguish various approaches to evaluating innovative activity. T. Nawrocki, for instance, distinguishes a group of methods used by several international and national institutions (e.g. Eurostat, GUS) for periodic research on innovative phenomena (Nawrocki, 2012). Among these methods it is worth to mention the methodology developed by the OECD, which is the most widespread international comparative innovation 
statistics developed by the Group of National Experts on Science and Technology Indicators (NESTI) with the participation of experts from other institutions and organisations (Oslo Manual 2018). The results of their work are published in a series of international methodological manuals called The Frascati Manuals. Oslo Manual and Frascati Manual are the key books to be used in terms of evaluating the innovativeness of companies. As far as the research and evaluation of innovative activity is concerned, the key methods are those based on the so-called RBV (resource-based view), a strategic management concept that places great emphasis on researching the resources and skills of an organisation (Nawrocki, 2012). The concept of resource-based view (RBV), as emphasised by R. Krupski, has evolved into one of the most renowned and effective in describing, explaining and predicting the organisation of RBT (resource-based theory) (Krupski, 2012). According to the resource-based approach, the success of an organisation is determined by its strategic potential in the form of appropriately selected resources and the ability to use them effectively (Pawłowski, 2005). Among the methods based on this approach it is possible to distinguish, for example, innovative audit, maturity models and excellence models.

According to Haffer, excellence models can be an efficient tool for managers focused on management improvement (Haffer, 2011). This is because excellence models help modern organisations to anticipate, measure, monitor the needs and requirements of stakeholders and follow the achievements of others (Martusewicz, Szumowski, 2018). A model of excellence can be considered as a set of guidelines used as a benchmark for self-assessment (Grigoroudis, Siskos, 2010) as well as external evaluation (Bovaird, Loffler, 2009). As Lichtarski (2014) underlines, organisational excellence models are increasingly popular, both holistic, such as the EFQM Excellence Model (Hakes, 2007), and those focused on selected areas, such as process or design excellence models or controlling excellence models or innovation management excellence models. Currently, models such as the Deming's model, EFQM or MBNQA serve as the basis for most of the excellence models emerging in the world. They have been developed according to the principles and values considered most essential for the long-term success of an organisation (Jasiulewicz-Kaczmarek, Prusak, 2012). One model, such as EFQM, was developed in 1991 with the support of the European Organisation for Quality and the European Commission and was designed as a practical and pragmatic tool to allow organisations to have a comprehensive overview of their current level of excellence and to prioritise their improvement activities in order to achieve the best results (EFQM). The EFQM excellence model consists of a set of three integrated components (EFQM):

- Fundamental concepts of excellence - defining the basic principles that serve as the basis for achieving sustainable excellence in an organisation.

- Model criteria - providing a framework to support organisations in transforming basic concepts and thinking into practice.

- RADAR - a tool for systematic improvement in all areas of the organisation. 
The implementation of these excellence models allows for a comprehensive review of the organisation, identifying strengths but also areas for improvement.

Excellence models are part of the concept of evaluating innovative activity which, because of its multidimensionality and complexity, imposes the search for ways and tools to measure it. The Bloom, Sadun and van Reenenen research, based on a large sample of companies in more than ten countries, shows that management practices explain many differences in performance among companies and are correlated with innovation (Bloom, Sadun, van Reenenen, 2012). The results of the authors' research suggest that there is a strong correlation between the quality of company management practices and the intensity of innovation in the company. Excellence models can, on the one hand, help decision-makers to assess, for instance, the state of innovation process management in their organisations and, on the other hand, make direct improvements (Saraph et al., 1989). They can also support continuous improvement (Pun, Gill, 2002) of innovation activities. These models can be used as a method of benchmarking to prioritise wider-scale activities (Enkel, Bell, Hogenkamp, 2011).

Based on the literature on the subject, the characteristics of three selected excellence models in the area of innovation management are presented:

1. A.T. Kearney House of Innovation.

2. Innovation Excellence Model (Arthur D. Little).

3. EFQM Innovation Excellence Builder.

A.T. Kearney's House of Innovation was developed by A.T. Kearney, an international consulting firm founded in 1926 by Andrew Thomas Kearney. The A.T. Kearney's House of Innovation is an example of a comprehensive, holistic approach to innovation management and presents the company's innovation development management structure (Žižlavský, 2011). This model focuses on the following five components for innovation management:

1. innovation strategy;

2. organisation and innovation culture;

3. innovation life-cycle management;

4. key factors supporting innovation management;

5. and the result of innovation management with respect to relevant key innovation performance indicators (Diedrichs, Engel, Wagner, 2006).

These dimensions focus on sustainable growth resulting from innovation. A.T. Kearney's House of Innovation assumes that the success of innovation management can only be made sustainable whether all dimensions are managed continuously at all levels of the company (Žižlavský, 2011). Based on the A.T. Kearney's House of Innovation, an Internet-based SelfAssessment Tool (SAT) for self-assessment of the level of innovation management in the company was developed as a result of the IMProve project. This project is a significant part of the Europe INNOVA initiative, which aims to improve innovation management. 
Arthur D. Little's Innovation Excellence Model was developed by the company Arthur D. Little founded in 1886. The company is a world leader in management consulting combining strategy, innovation and technology with industry knowledge. The model is used to test innovation excellence by taking into account (Pathways to Innovation Excellence..., 2010):

- new business innovations,

- innovation strategies,

- measuring and managing innovation,

- innovative processes (from applying the right business intelligence to managing their product or service portfolio).

This model can be used for comparison with other companies based on the benchmarking method of the results obtained from the diagnostic test and enables the analysis of processes and approaches used by companies to manage innovation (Arthur D. Little). It also helps to understand how to improve one's innovation practices, how they contribute to innovation success and which innovation management techniques need to be implemented to achieve better results from innovation activities (Arthur D. Little). The main results of the research based on Arthur D. Little's Model show that (Arthur D. Little):

- excellence in model-based innovation management leads to higher innovation performance,

- leading innovators get higher profits from new products and services in less time than average contractors,

- most companies are not satisfied with their innovation performance,

- the best innovators do much better when they adopt best practices for accelerating growth.

EFQM Innovation Excellence Builder is based on the EFQM Excellence Model and is intended to lead to a formal accreditation showing the organisation's commitment to innovation (EFQM Innovation Excellence Builder). The EFQM Innovation Excellence Builder was developed as one of the new joint efforts with the Centre for Competitiveness, which has been an active national partner of EFQM (EFQM Innovation Excellence Builder) since 1994. The Innovation Excellence Builder programme is supported by the Innovate XL software platform (EFQM Innovation Excellence Builder). Using the survey it is possible to conduct an online assessment and identify strengths and organisational capabilities in the following areas: innovation direction, innovation delivery, innovative climate, innovation results. The structure of Innovation Excellence and the relations of the EFQM Excellence Model are presented in Table 1. 
Table 1.

The structure of innovation excellence and the relations of the EFQM Excellence Model

\begin{tabular}{|c|c|}
\hline Structure of Innovation Excellence & Relations of the Excellence Model \\
\hline $\begin{aligned} & \text { Innovation direction } \\
&- \text { Vision and Leadership } \\
&- \text { Strategy } \\
&- \text { Resources }\end{aligned}$ & $\begin{array}{l}\text { Leadership } \\
\text { Strategy } \\
\text { People } \\
\text { Resources }\end{array}$ \\
\hline $\begin{array}{cl}\text { Innovation environment } \\
-\quad \text { Possibilities } \\
-\quad \text { Innovative culture } \\
-\quad \text { Collaboration } \\
\end{array}$ & $\begin{array}{l}\text { Leadership } \\
\text { Strategy } \\
\text { People } \\
\text { Partnership and resources }\end{array}$ \\
\hline $\begin{aligned} & \text { Innovation provision } \\
&-\quad \text { Processes } \\
&- \text { Knowledge management } \\
&- \text { Sustainability } \\
&\end{aligned}$ & $\begin{array}{l}\text { Leadership } \\
\text { Strategy } \\
\text { People } \\
\text { Partnership and resources } \\
\end{array}$ \\
\hline $\begin{array}{ll}\text { Value creation } \\
\text { - } \\
\text { - Impact on business (Finance/Process/Customer) } \\
\text { - } \quad \text { Impact on market } \\
\text { Impeople }\end{array}$ & All result criteria \\
\hline
\end{tabular}

Source: own elaboration based on: External assessment \& Recognition levels - EFQM, Available online https://middleeast.efqm.org/index.php/innovation-excellence/external-assessment-recognition-levels/.

The framework of the Innovation Excellence Builder is built on the EFQM Excellence Model, based on both the model criteria and the RADAR concept.

When comparing the discussed excellence models in innovation management, the table below shows their characteristics in terms of several classification criteria.

Table 2.

Elements of excellence models in innovation management

\begin{tabular}{|c|c|c|c|}
\hline & $\begin{array}{c}\text { A.T. Kearney } \\
\text { House of Innovation }\end{array}$ & $\begin{array}{c}\text { Arthur D. Little } \\
\text { Innovation Excellence Model }\end{array}$ & $\begin{array}{l}\text { EFQM Innovation } \\
\text { Excellence Builder }\end{array}$ \\
\hline $\begin{array}{l}\text { Organisations } \\
\text { involved in } \\
\text { the study }\end{array}$ & $\begin{array}{l}\text { Consulting firm } \\
\text { A.T. Kearney }\end{array}$ & $\begin{array}{l}\text { Consulting firm } \\
\text { Arthur D. Little }\end{array}$ & $\begin{array}{c}\text { EFQM, } \\
\text { Centre for Competitiveness }\end{array}$ \\
\hline Scope & Consultancy & Consultancy & Consultancy, standardization \\
\hline $\begin{array}{l}\text { Main elements } \\
\text { of the model }\end{array}$ & $\begin{array}{l}\text { - innovative organisation } \\
\text { and culture } \\
\text { - innovation strategy } \\
\text { - innovation life-cycle } \\
\text { management } \\
\text { - key factors supporting } \\
\text { innovation management } \\
\text { - results of innovation } \\
\text { management } \\
\text { These dimensions focus on } \\
\text { sustainable growth through } \\
\text { innovation }\end{array}$ & $\begin{array}{l}\text { - innovation strategy } \\
\text { - resource and competency } \\
\text { management } \\
\text { - idea management } \\
\text { - product portfolio } \\
\text { management } \\
\text { - technology portfolio } \\
\text { management } \\
\text { - Business Intelligence } \\
\text { - development and launch } \\
\text { - post-launch } \\
\text { - focus on growth } \\
\text { - innovation results }\end{array}$ & $\begin{array}{l}\text { - innovation direction (vision, } \\
\text { leaders, strategy, resources) } \\
\text { - innovation environment } \\
\text { (possibilities, innovative } \\
\text { culture, collaboration) } \\
\text { - innovation provision } \\
\text { (processes, knowledge } \\
\text { management, sustainability) } \\
\text { - Value creation and impact } \\
\text { on business (business, } \\
\text { market, people) }\end{array}$ \\
\hline
\end{tabular}

Source: own elaboration based on: Diedrichs, E., Engel, K., Wagner, K.: European Innovation Management Landscape. Europe INNOVA paper No. 2, Augsburg: Druckerei, 2006; Pathways to Innovation Excellence - Results of a Global Study by Arthur D. Little, Arthur D. Little 2010; https://www.efqm.org/index.php/excellence-builders/innovation-excellence/innovation-excellenceprogramme. 
From the presented description of the models it appears that these are approved innovation management assessment tools, developed as consulting models (A.T. Kearney's model, Arthur D. Little's model) and global models (VIVA model, EFQM Innovation Excellence Builder). The presented model characteristics indicate the existence of common areas of analysis relating to innovation management despite differences in the approach adopted. Among these common areas of analysis, we can distinguish: innovation process management, innovation strategies and results orientation.

Presented analyses show that knowledge about the level of development of applied innovation management practices in a given enterprise may support the improvement of innovation activity effectiveness. The research conducted by Bloom, Sadun and Van Reenen shows that there is a great degree of diversity in the quality of applied management practices among the surveyed enterprises and that many companies are not aware of the level of their quality (Bloom, Sadun and Van Reenen, 2012). Hence, there is a need to inspire companies to assess and compare their innovation management skills and to improve them with e.g. excellence models.

\section{Conclusion}

In conclusion, a literature review on methods of assessing innovative activities should emphasise the multidimensionality and complexity of the issue and, therefore, the difficulties in measuring and assessing it. There is no single commonly accepted method of assessing innovative activity of enterprises. Depending on the needs, different methods and approaches can be applied to its assessment. In this context, the significance of excellence models that fit into the concepts of assessing innovative activity and innovation management practices in enterprises based on the $R B V$ (resource-based view) approach has been emphasised.

Based on the literature analysis of the selected models, it can be concluded that the existing excellence models have established principles and assessment criteria and provide opportunities for improvement in the pursuit of excellence in the results achieved. When comparing the described models for assessing the innovative activity of an organisation, both similarities and differences can be observed. When looking for similarities, it can be concluded that these are mostly widely recognised diagnostic concepts, which are intended to provide a comprehensive, holistic approach to innovation management in an organisation. These models focus not only on factors, but also on the results of innovative activity, while making recommendations for improving innovative activity. The models differ mainly in their approach to describing and assessing the individual elements of the models according to their principles and values. 
By emphasising the significance of these models, many practical aspects of the application of research on excellence models in terms of innovation management can be identified. These models allow, first and foremost, business managers to better understand and assess innovation activity. This knowledge may be exceptionally helpful in further refining the mechanisms for managing innovative activities of enterprises. Therefore, further conceptual work on excellence models for the assessment of innovative activity, taking into account the modern conditions of business development and paradigms in the area of management and quality sciences, and testing them in empirical research, are desirable directions for research.

\section{References}

1. Arthur D. Little's Global Innovation Excellence Survey. Retrieved from https://www.adlittle.com/en/insights/viewpoints/arthur-d-little\%E2\%80\%99s-globalinnovation-excellence-survey, 19.05.2019.

2. Bloom, N., Sadun, R., and Van Reenen, J. (2012). The Organization of Firms Across Countries. The Quarterly Journal of Economics, 1-43.

3. Bovaird, T. and Loffler, E. (2009) (Eds.). Public Management and Governance. Oxon: Routledge.

4. Brocke, J., and Rosemann, M. (Eds.) (2010/2015). Handbook on Business Process Management 2. Strategic Alignment, Governance, People and Culture. Berlin-Heidelberg: Springer-Verlag.

5. Dervitsiotis, K.N. (2010). A framework for the assessment of an organisation's innovation excellence. Journal Total Quality Management \& Business Excellence, Vol. 21, Iss. 9.

6. Diedrichs, E., and Engel, K., and Wagner, K. (2006). European Innovation Management Landscape. Europe INNOVA, paper No. 2, Augsburg: Druckerei. Retrieved from https://www.improve-innovation.eu/wp-content/uploads/2010/07/IMProveEUInnoMgmt Landscape2006.pdf, 19.05.2019.

7. EFQM Innovation Excellence Builder. Available online https://www.efqm.org/index.php/ excellence-builders/innovation-excellence/innovation-excellence-programme/, 17.02.2019.

8. EFQM. Available online http://www.efqm.pl/, 17.02.2019.

9. Enkel, E., and Bell, J., and Hogenkamp, H. (2022). Open Innovation Maturity Framework. International Journal of Innovation Management, Vol. 15, No. 6. Imperial College Press, pp. 1161-1189.

10. External assessment \& Recognition levels - EFQM. Available online https://middleeast.efqm.org/index.php/innovation-excellence/external-assessmentrecognition-levels/, 17.02.2019. 
11. Grigoroudis, E., and Siskos, Y. (2010). Customer Satisfaction Evaluation. Methods for Measuring and Implementing Service Quality. New York: Springer Science+Business Media.

12. Haffer, R. (2011). Samoocena i pomiar wyników działalności w systemach zarzadzania przedsiębiorstw. Toruń: Wydawnictwo Naukowe Uniwersytetu Mikołaja Kopernika.

13. Hakes, Ch. (2007). The EFQM Excellence model for Assessing Organizational Performance: A management Guide (Best Practice).

14. Harrington, H.J. (2006). Process Management Excellence. The Five Pillars of Organizational Excellence. Paton Press.

15. IMProve. Available online www.improve-innovation.eu, 17.02.2019.

16. Jasiulewicz-Kaczmarek, M., and Prussak W. (2012). Modele doskonałości w zarządzniu jakością. Zarządzanie i Finanse, tom 10, nr 3/1.

17. Juchniewicz, M. (2016). Osiąganie doskonałości w realizacji projektów przy wykorzystaniu modeli dojrzałości projektowej. In: M. Trocki and E. Bukłaha (Eds.), Zarzadzanie projektami - wyzwania $i$ wyniki badań. Warszawa: Oficyna Wydawnicza Szkoła Główna Handlowa.

18. Kacała, J. (2013). Wewnętrzna logika relacji w modelu EFQM a doskonałość organizacyjna. In: Wiedza w zarządzaniu współczesną organizacją. Prace Naukowe Uniwersytetu Ekonomicznego we Wrocławiu, nr 299.

19. Kłosowska-Lasek, K. (2019). Dążenie do doskonałości jako wyraz kultury doskonalenia w jednostkach samorządu terytorialnego. In: Kulturowe uwarunkowania zarządzania i komunikowania w organizacjach publicznych, Prace Naukowe Uniwersytetu Ekonomicznego w Katowicach, Wrocław.

20. Krupski, R. (2012). Rozwój szkoły zasobów zarządzania strategicznego. Przeglad Organizacji, $\mathrm{Nr}$ 4(867).

21. Lichtarski, J.M. (2014). Ewolucja kryteriów oceny doskonałości struktury organizacyjnej. Prace Naukowe Uniwersytetu Ekonomicznego we Wrocławiu, nr 359, Uniwersytet Ekonomiczny we Wrocławiu.

22. Martusewicz, J. and Szumowski W. (2018). Modele dojrzałości a modele doskonałości. Niezależność czy współzależność na drodze do rozwoju organizacji. Organizacja i Kierowanie. $n r$ 1(180). Warszawa: Komitet Nauk Organizacji i Zarządzania Polskiej Akademii Nauk, Szkoła Główna Handlowa w Warszawie, Kolegium Zarządzania i Finansów, pp. 63-78.

23. Mielcarek, P. (2017). Ewolucyjne czy rewolucyjne - które podejście jest skuteczniejsze w rozwoju procesu innowacji? SiP WNEiZ US nr 48/3.

24. Nawrocki, T. (2012). Innowacyjność produktowa przedsiębiorstw. Metodyka oceny na przykładzie spółek giełdowych. Warszawa: CEDEWU.

25. Nowosielski, K. (2012). Doskonalenie jakości controllingu w przedsiębiorstwie. In: Metody badania i modele rozwoju organizacji. Monografie, Mfiles. 
26. Oslo Manual 2018. The Measurement of Scientific, Technological and Innovation Activities Oslo Manual 2018. Guidelines for collecting, reporting and using data on innovation Oslo Manual 2018, OECD/EUROPEAN UNION 2018.

27. Pathways to Innovation Excellence - Results of a Global Study by Arthur D. Little, Arthur D. Little 2010. Available online https://www.adlittle.com/sites/default/files/viewpoints/ ADL_InnoEx_Report_2010.pdf, 18.05.2019.

28. Pawłowski, J. (2005). Innowacyjność i konkurencyjność przedsięwzięć gospodarczych. Ekonomika i Organizacja Przedsiębiorstwa, nr 8, pp. 41-47.

29. Peters, T.J. (1991). Thriving on Chaos: Handbook for a Management Revolution. London: Harper Collins Publisher.

30. Peters, T.J. and Waterman, R.H. (1982). In Search of Excellence - Lessons from America's Best-Run Companies. London: Harper Collins Publisher.

31. Pun, K., and Gill, R. (2002). Integrating EI/TQM efforts for performance improvement: a model. Integrated Manufacturing Systems, Vol. 13, No. 7, pp. 447-458.

32. Saraph, J.V., Benson, P,G. \& Schroeder, R.G. (1989). An instrument for measuring the critical factors of total quality management. Decision Sciences, 20.

33. Spitzley, A. and Rogowski, T. and Garibaldo, F. (Eds.) (2007). Open Innovation for small and medium sized Enterprises. Ways to develop Excellence. Stuttgart: Fraunhofer-Institute for Industrial Engineering and authors.

34. Stańczyk-Hugiet, E. (2014). Ewolucja koncepcji doskonałości jako egzemplifikacja różnicowania, Prace Naukowe Uniwersytetu Ekonomicznego we Wrocławiu, nr 359, pp. 282-283.

35. Szczepańska, K. (2011). Zarządzanie jakościa. W dążeniu do doskonałości. Warszawa: Wydawnictwo C.H. Beck.

36. Szczepańska, K. (2012), Doskonalenie i samoocena w zarządzaniu jakością w przedsiębiorstwie. Problemy Zarzadzania, 10/2, pp. 9-27.

37. Tatarkiewicz, W. (1976). O doskonałości. Warszawa.

38. Zbierowski, P. (2012). Orientacja pozytywna organizacji wysokiej efektywności. Warszawa: Oficyna a Wolters Kluwer business.

39. Žižlavský O. (2011). House of innovattion - holistic diagnostic approach to practises in innovation management. AD Alta: Journal of Interdisciplinary Research, vol. 1, no. 1, pp. 79-83. 